$\sqrt{B}$

J. Bio-Sci. 27: 121-132, 2019

ISSN 1023-8654

http://www.banglajol.info/index.php/JBS/index

DOI: https://doi.org/10.3329/jbs.v27i0.44677

\title{
GROWTH PATTERN OF FRESHWATER BIVALVE MOLLUSK LAMELLIDENS MARGINALIS (LAMARCK, 1819) FROM THE NORTHWEST BANGLADESH
}

\author{
DA Nahar, MR Islam, MS Islam, S Jasmine and MMR Mondol* \\ Department of Fisheries, Faculty of Agriculture, University of Rajshahi, Rajshahi-6205, Bangladesh
}

\begin{abstract}
Growth, morphometry and length-weight relationships of the freshwater mussel Lamellidens marginalis (Lamarck, 1819) was studied during January 2014 and May 2015. Sampling was carried out monthly and a total of 560 specimens were collected from Rajshahi district, northwest of Bangladesh. The recorded length -breadth and length-width relationships were $B=0.179+0.475 \mathrm{~L}$ and $W=0.196+$ $0.3163 \mathrm{~L}$ respectively. The length-total weight, length-wet tissue weight, length-dry tissue weight, lengthshell weight, length-dry shell weight relationships were $W=0.1241 \mathrm{~L}^{2.9066}, \mathrm{~W}=0.0524 \mathrm{~L}^{2.7377}, \mathrm{~W}$ $=0.0116 \mathrm{~L}^{2.7849}, \mathrm{~W}=0.0533 \mathrm{~L}^{2.9178}$ and $\mathrm{W}=0.0391 \mathrm{~L}^{3.0386}$ respectively. Monthly $b$ values of length-lengths and length-weights relationships indicated a negative allometric growth pattern except length-shell weights relationships which showed an isometric growth of the mussel. This study is the first report on growth pattern of Lamellidens marginalis from Bangladesh and the results would be useful for fishery managers to impose adequate regulations for a sustainable fishery management of this species in the freshwater ecosystem in Bangladesh.
\end{abstract}

Key words: Allometry, Freshwater mussel, Growth, Lamellidens marginalis, Morphometry

\section{Introduction}

The morphometric relationships between length and weight can be used to assess the well-being of individuals and to determine possible differences between separate unit stocks of the same species (King 2007). In addition, length-length relationships are also important in fisheries management for comparative growth studies. Allometry is most reliable and widely used method to study the growth pattern of bivalve. The allometric principle of animal morphology has long been recognized since Huxley and Tessier (1936) who proposed the concept of allometry. Allometry is the study of relationship between two measurable variables, or in its most general sense- size and its consequences (Reiss 1989). The allometric relationships are generally explained by shell growth along the three dimensional axis. The study of shell dimensions in molluscs is aimed at ascertaining the interrelationships in growth of body characters. The influence of proximate or mechanistic factors will cause differences in the intercept and slope of the allometry. In allometric length-weight relationship, the variation in equilibrium constant represents the growth in weight than that of length. Relatively large variation in meat content occurs in bivalve molluscs depending upon the variation in physiological condition and environmental variables (Wilbur and Owen 1964). The biology of freshwater mussels viz., Parreysia corrugata (Nagabhushanam and Lomte 1971, Lomte and Jadhav 1980) Parreysia favidens (Ramesha and Sophia 2015) and Lamellidens spp. (Narian 1972, Nagabhushanam and Lohgaonker 1978, Moorthy et al. 1983) inhabiting in the freshwater habitat have been reported previously. However, no data are available on growth pattern of freshwater mussels $L$. marginalis from Bangladesh. Even though L. marginalis is listed as least concern by IUCN (Budha and Daniel 2010), they are potentially susceptible to a number of threats as over harvesting, environmental degradation, alteration of water body

*Author for correspondence: mostafiz_bau@yahoo.com 
into crop land, water pollution, lack of proper knowledge on biological aspects of this species. Understanding their biological functions within aquatic ecosystems is vital for successful management. Therefore, the present study was undertaken to know the growth pattern (length-length relationship and length-weight relationship) of $L$. marginalis inhabiting the freshwater ecosystem, in Rajshahi, the northwest Bangladesh.

\section{Materials and Methods}

\section{Study site}

Freshwater bivalve L. marginalis were collected at monthly intervals during January 2014 and May 2015 from

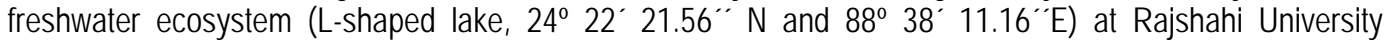
Campus, Rajshahi, the northwest Bangladesh, where the wild stock of the L. marginalis is available (Fig. 1).

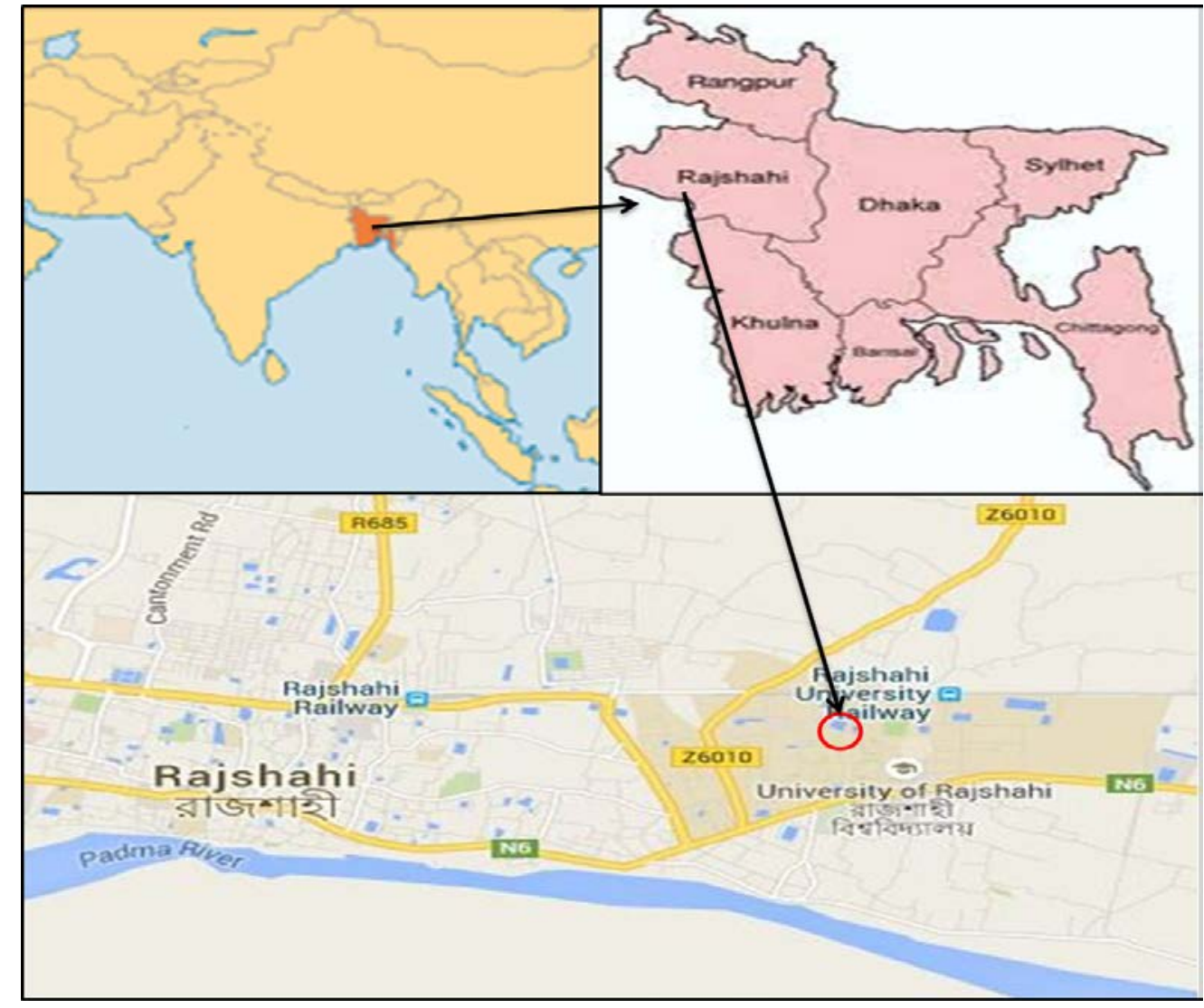

Fig. 1. Map showing the study area (red circle indicating the study site).

\section{Sampling and biometric measurements}

A total of 560 individuals of $L$. marginalis were collected during the study period and subjected to morphometric measurements. Shell length (maximum antero-posterior distance), breadth (maximum distance from hinge to ventral margin) and width or depth or thicknesses (maximum distance between outer 
edges of two valves) of individual organisms were measured accurately to $0.01 \mathrm{~mm}$ using Vernier calipers. Total weight of individual mussels was taken. The mussels were dissected to remove the meat which was then blotted and weighed individually. The individual weight of shell was also determined. Both the meat and shell were dried at constant temperature of $60^{\circ} \mathrm{C}$ for 2 days and weighed accurately to $0.01 \mathrm{~g}$ using an electronic balance. Allometric examination was done for morphometric (length-breadth and length-width) and length-weight (length-total weight, length-wet tissue weight, length-dry tissue weight, length-shell weight and length-shell dry weight) relationships (Pauly 1983).

\section{Statistical analysis}

A nonparametric Kruskal-Wallis test was used to know the distribution of all the length-weight measurements across the categories of sex. Dimensional relationships were estimated using the linear regression equation $(Y=a+b X)$ and the length-weight relationship by a non-linear regression equation $\left(W=a L^{b}\right)$ in which, $a$ (intercept) and $b$ (slope / equilibrium constant) are constants. A t-test $(\mathrm{HO}, \mathrm{b}=3)$ was performed with $a$ confidence level of $95 \%$ to confirm if the values of $b$ obtained by linear regression were significantly different from the isometric value, expressed by the following equation $t s=(b-3) / S b$, where ts $=t$-test value, $b=$ slope, $\mathrm{Sb}=$ standard error of the slope (b). Subsequently, comparison between the obtained value of $t$ - test and the tabled critical value of $t$-test, allowed the determination of the statistical significance of the $b$ value. To know the temporal variation of growth parameters a one way ANOVA with DUNCAN POSTHOC ranking was used. All the statistical analysis were performed on SPSS (version 20.0) software at $p<0.05$ level of significance.

\section{Results}

\section{Shell and tissue growth}

During this study there was no significant differences $(p<0.05)$ observed in the distribution of all the lengthweight measurements across the categories of sex (Kruskal-Wallis Test, $p>0.05$ ). That's why all the morphometric measurements and length-weight relationships were studied for combined sex. Table 1 represents the overall descriptive statistics of the shell length, shell breadth, shell width, body weight, tissue weight, shell weight, tissue dry weight and shell dry weight of $L$. marginalis. During this study minimum shell length was $3.65 \mathrm{~cm}$, maximum shell length was $10.55 \mathrm{~cm}$ and mean shell length was $7.33 \mathrm{~cm}$. Conversely minimum body weight was $3.60 \mathrm{~g}$, maximum body weight was $124.05 \mathrm{~g}$ and the mean body weight was $46.14 \mathrm{~g}$. A one way ANOVA indicated a significant monthly variation of the length and weight of $L$. marginalis during this study (Fig. 2-3, p<0.05).

Table 1. Descriptive statistics of shell length, shell breadth, shell width, body weight, tissue weight, tissue dry weight, shell weight and shell dry weight of $L$. marginalis during the study

\begin{tabular}{ccccc}
\hline Measurements & $n$ & Minimum & Maximum & Mean $( \pm \mathrm{SE})$ \\
\hline Shell length $(\mathrm{cm})$ & & 3.65 & 10.55 & $7.33 \pm 0.06$ \\
Shell breadth $(\mathrm{cm})$ & & 1.38 & 5.98 & $3.65 \pm 0.03$ \\
Shell width $(\mathrm{cm})$ & \multirow{5}{*}{560} & 1.21 & 3.64 & $2.52 \pm 0.03$ \\
Body weight $(\mathrm{g})$ & & 4.70 & 124.05 & $46.30 \pm 0.99$ \\
Tissue weight $(\mathrm{g})$ & & 1.30 & 46.43 & $13.66 \pm 0.30$ \\
Shell weight $(\mathrm{g})$ & & 0.33 & 11.21 & $3.33 \pm 0.07$ \\
Shell dry weight $(\mathrm{g})$ & & 1.55 & 51.25 & $20.86 \pm 0.46$ \\
\hline
\end{tabular}




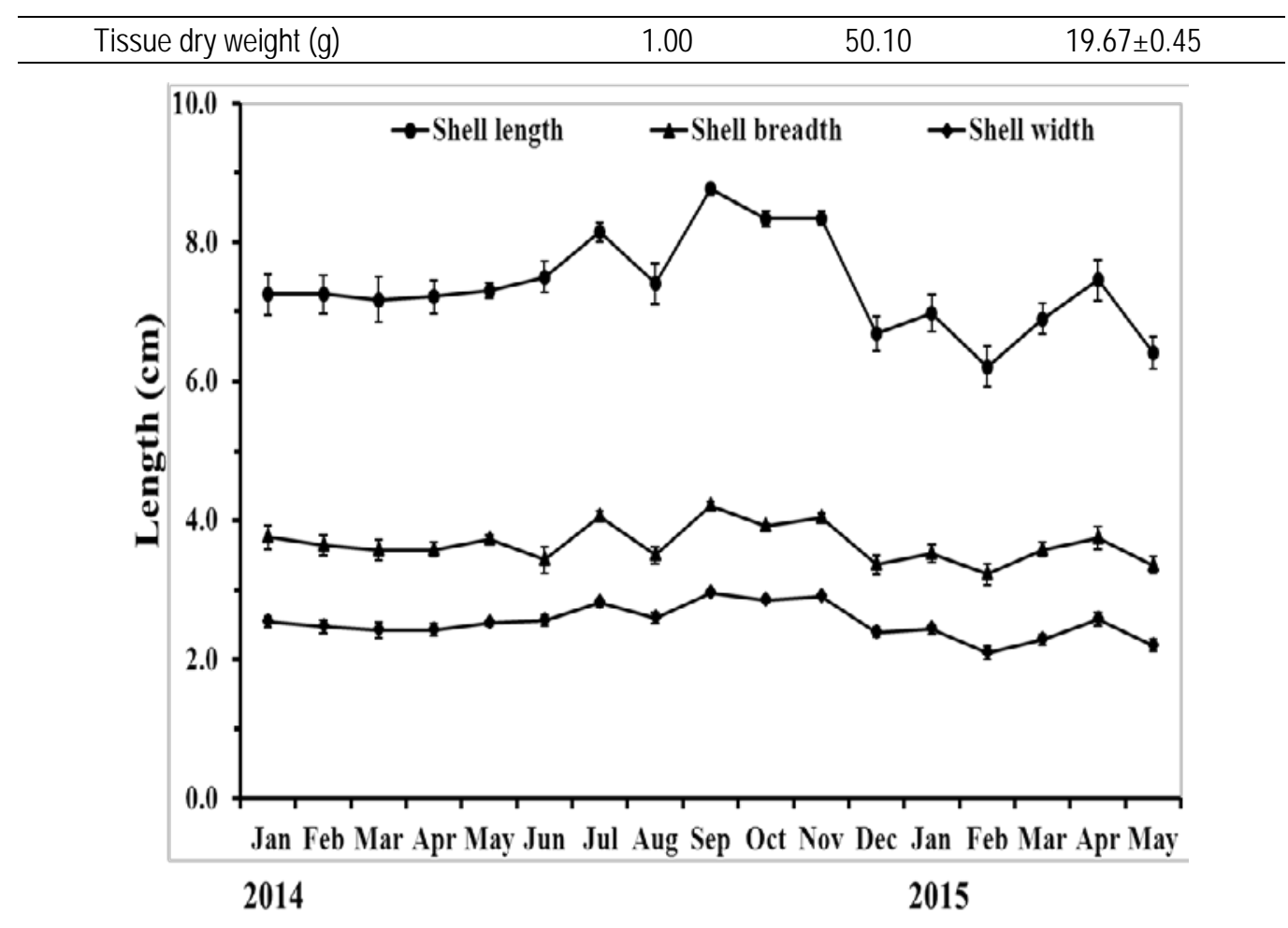

Fig. 2. Monthly variation (mean \pm SE) of shell length, shell breadth, shell width of $L$. marginalis (Lamarck 1819) during the study. Vertical bars represent standard error.

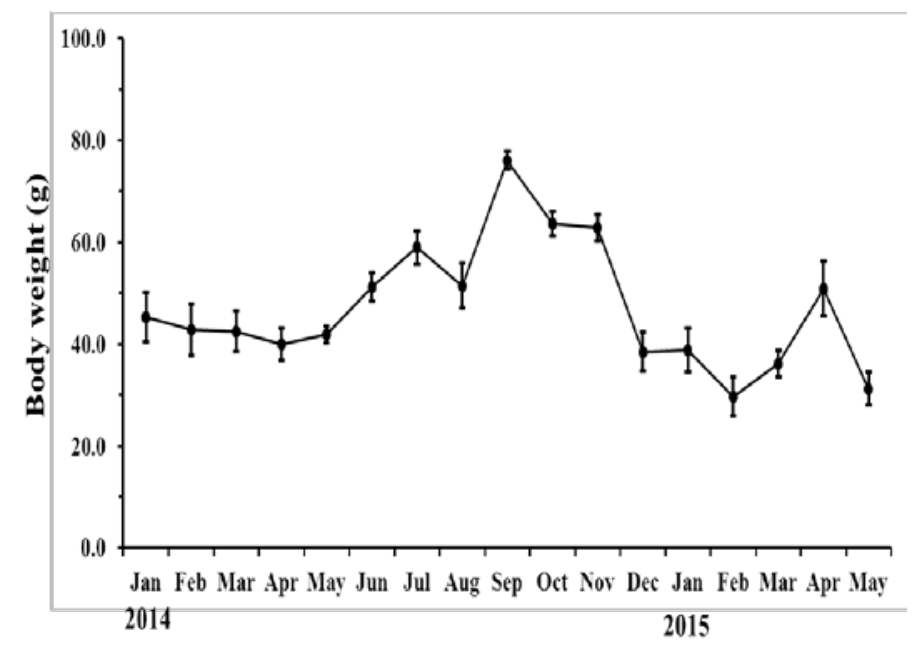

Fig. 3. Monthly variation (mean $\pm \mathrm{SE}$ ) of body weight of $L$. marginalis (Lamarck 1819) during the study. Vertical bars represent standard error. 


\section{Morphometric relationship}

The data on morphometric relationships (length-breadth and length-width) are shown in Fig. 4. This study data revealed that the length-length variables were linearly related. Further the data depicted that long individuals are wide (more height) and high (more thickness) and inversely the short individuals are narrow (less height) and low (less thickness). The calculated values of length-breadth and length-width relationships were $B=0.179+0.475 \mathrm{~L}$ and $W=0.196+0.3163 \mathrm{~L}$ respectively (Fig. 4). The linear relationships of lengthbreadth and length-width of $L$. lamellidens during the study period showed that the short individuals were of less height/thickness and inversely long individuals were wide/high (Fig. 4). The monthly $b$ values of lengthbreadth relationship varied from 0.3466 (October 2014) to 0.8132 (July 214) whereas for length-width relationship, the values ranged from 0.2495 (February 2014) to 0.3982 (August 2014) (Fig. 5)
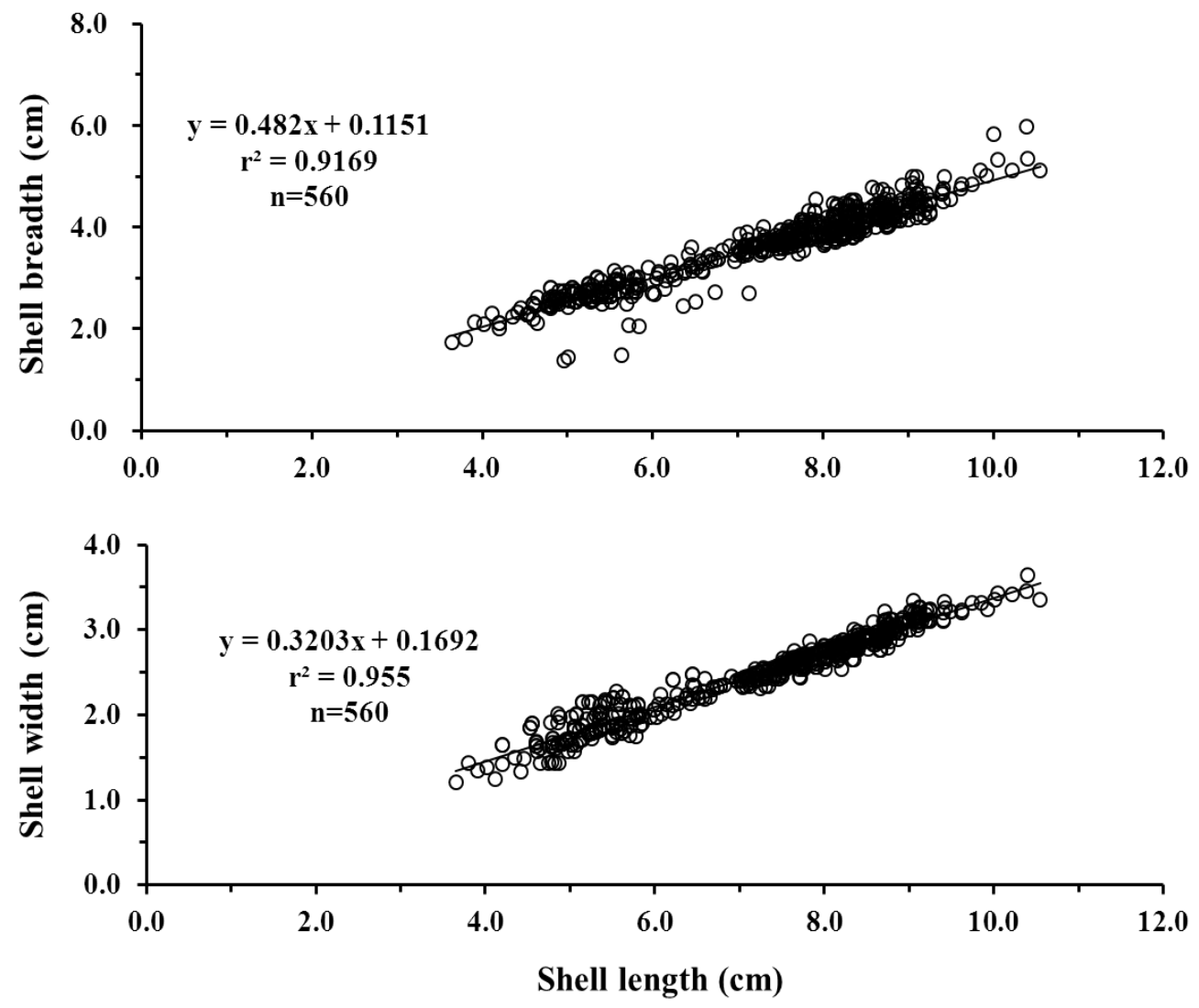

Fig. 4. Bivariate scatter diagram of length-breadth and length-width relationships of $L$. marginalis during the study. 


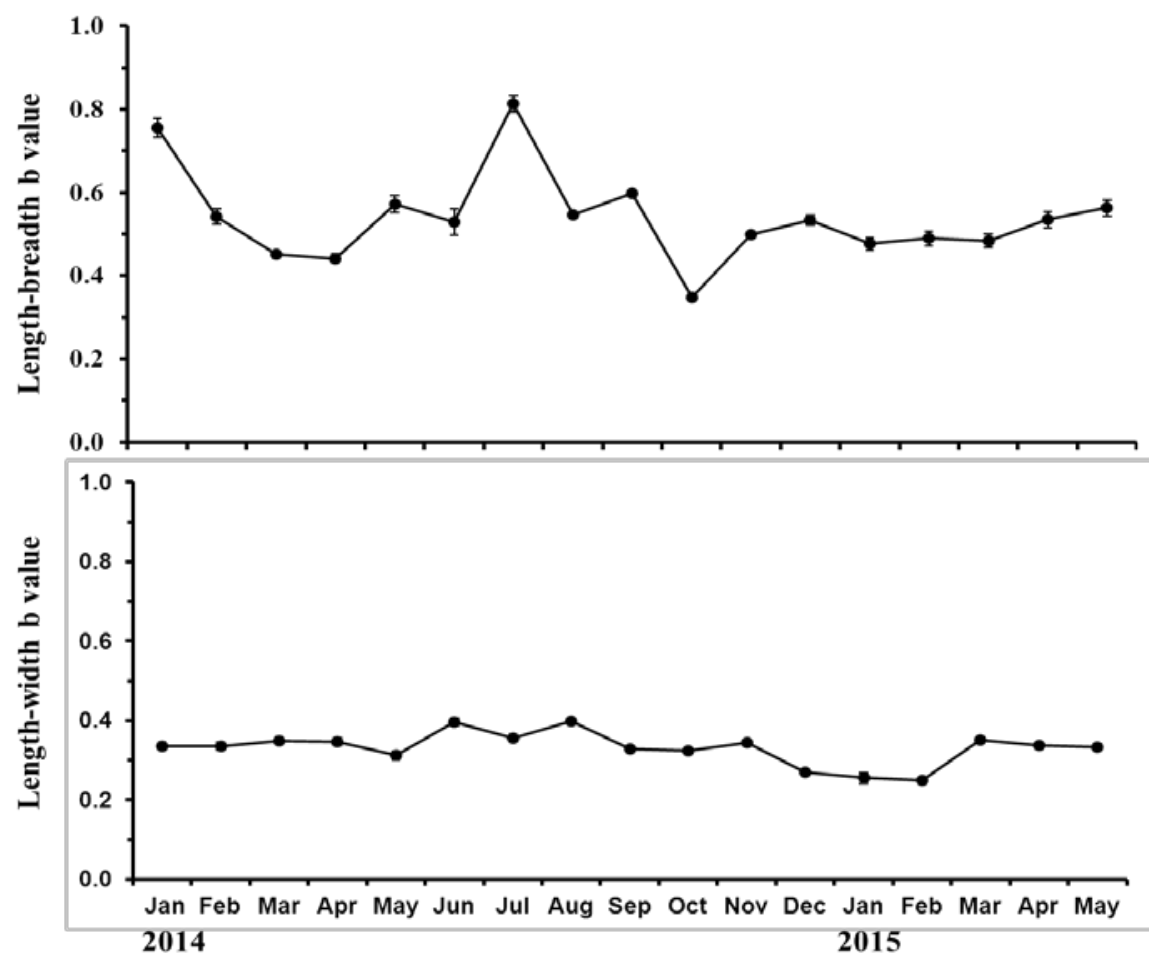

Fig. 5. Monthly variability in the $b$ values of length-breadth and length-width relationships of $L$. marginalis during the study. Vertical bars represent standard error.

\section{Length-weight relationship}

A non-linear relationship was noticed in all the measured length-weight relationships in all sizes and all the length -weight relationships were highly significant $(p<0.05)$. The nonlinear relationships of length-body weight, length-wet tissue weight, length-dry tissue weight, length-shell weight, length-dry shell weight were W $=0.1241 \mathrm{~L}^{2.8282}, \mathrm{~W}=0.0524 \mathrm{~L}^{2.5905}, \mathrm{~W}=0.0116 \mathrm{~L}^{2.6296}, \mathrm{~W}=0.0533 \mathrm{~L}^{2.8769}$ and $\mathrm{W}=0.0391 \mathrm{~L}^{2.9979}$ respectively (Fig.6-8). The monthly equilibrium constant (b) values of length-weight relationships were 1.8037 (July 2014) and 3.5011 (June 2014) for length-total weight, between 1.8185 (July 2014) and 3.6224 (May 2014) for length-wet tissue weight, between 1.6247 (May 2014) and 3.7295 (July 2014) for length-dry tissue weight, between 2.1091 (March 2015) and 3.7399 (June 2014) for length-shell weight and between 2.2617 (April 2015) and 3.8662 (June 2014) for length-shell dry weight (Fig. 9-11). The $b$ values of length- body weight relationships showed some monthly variations. During January and February, 2014, $b$ value was slightly higher than 3, decreased from February to April and then rapidly increased at reaching the highest value 3.5011 in the month of June, 2014. From June to July a sharp decline of $b$ value was observed and then the $b$ value again increased from August to onward at reaching the value more than 3 during the winter in 2015. The $b$ value of length-tissue weights and length- shell weights relationship represented almost same pattern during this study (Fig. 10-11). 


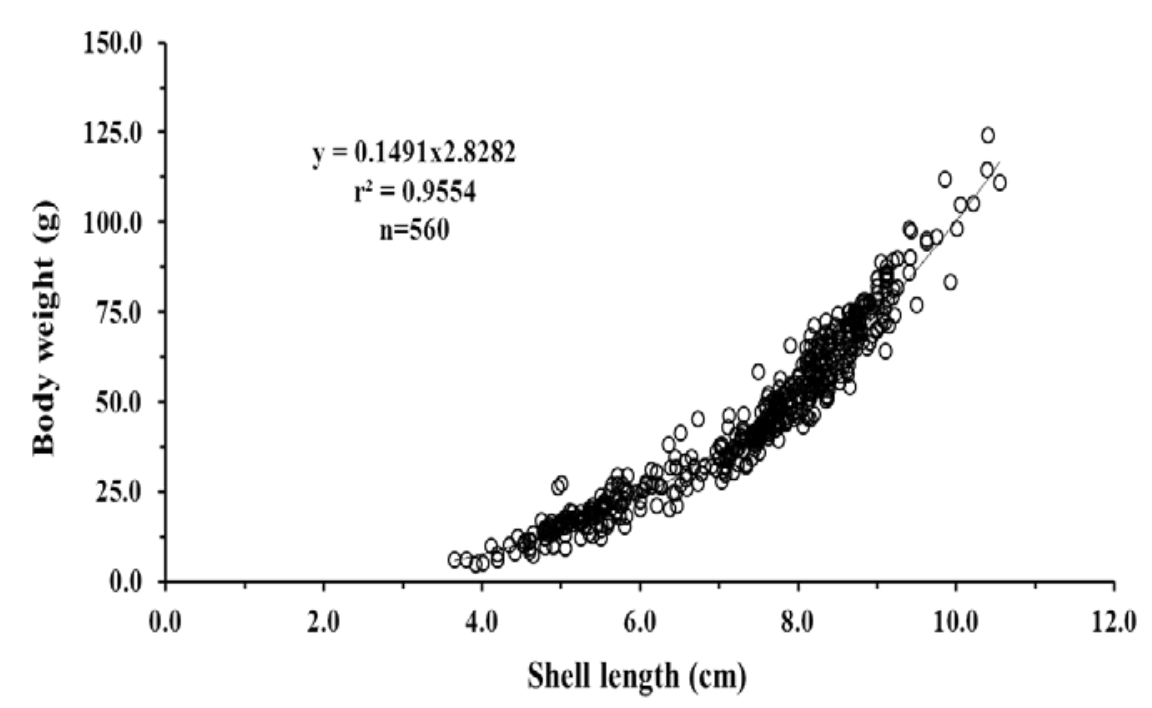

Fig. 6. Bivariate scatter diagram of length-body weight relationships of $L$. marginalis.
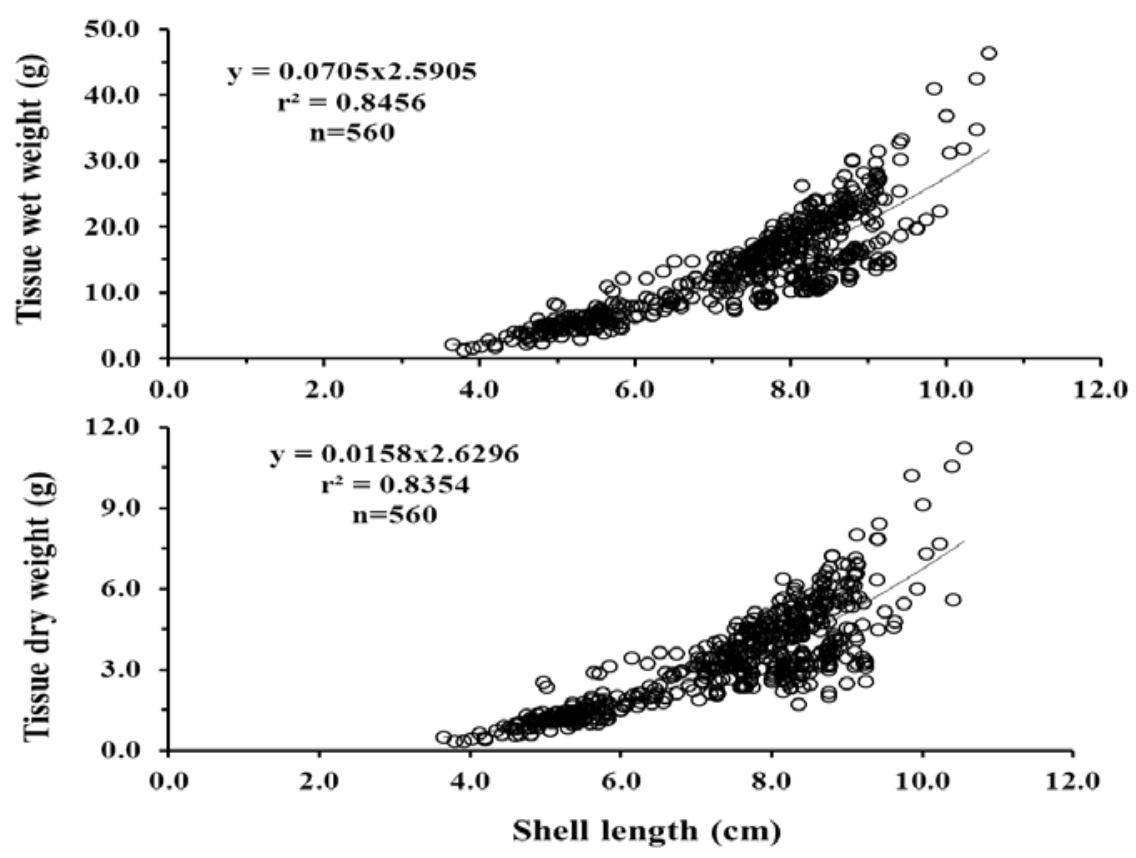

Fig. 7. Bivariate scatter diagram of length-tissue weight and length-tissue dry weight relationships of $L$. marginalis. 

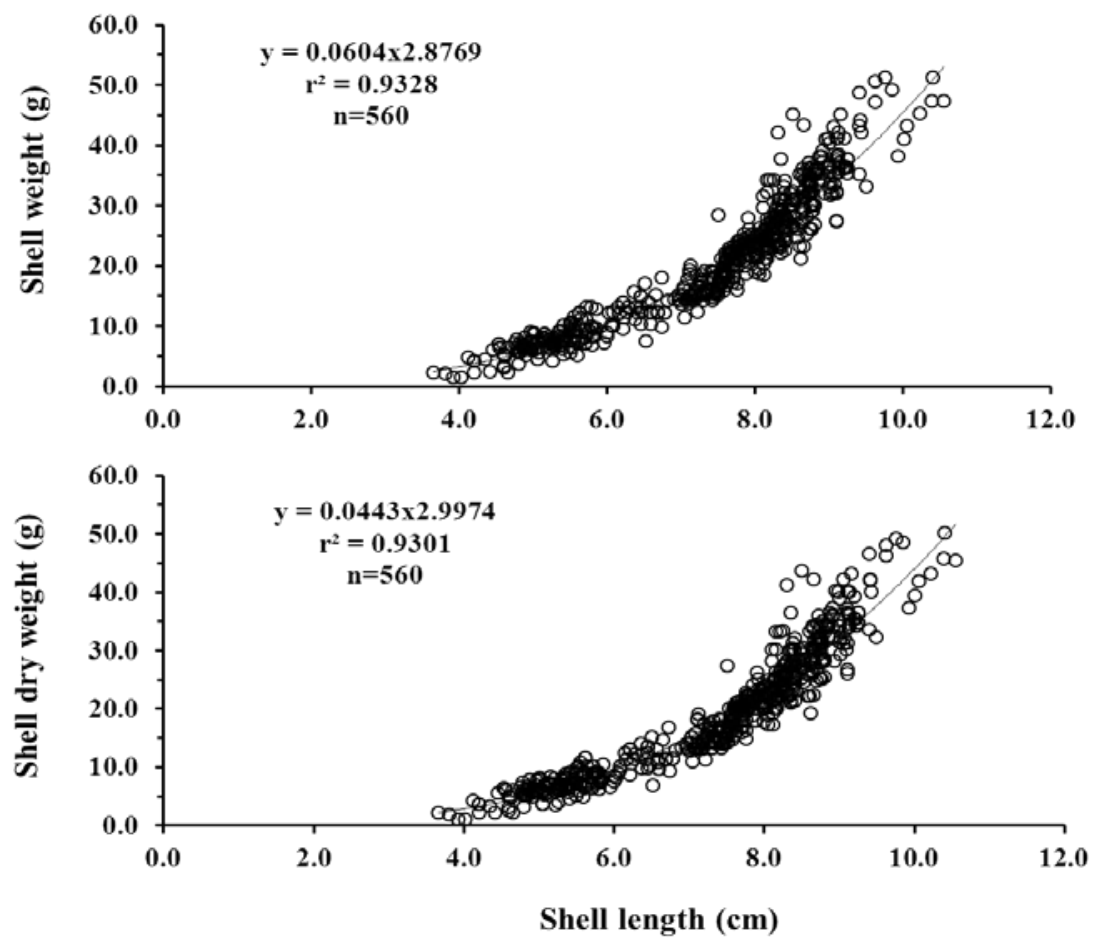

Fig. 8. Bivariate scatter diagram of length-shell weight and length-shell dry weight relationships of $L$. marginalis.

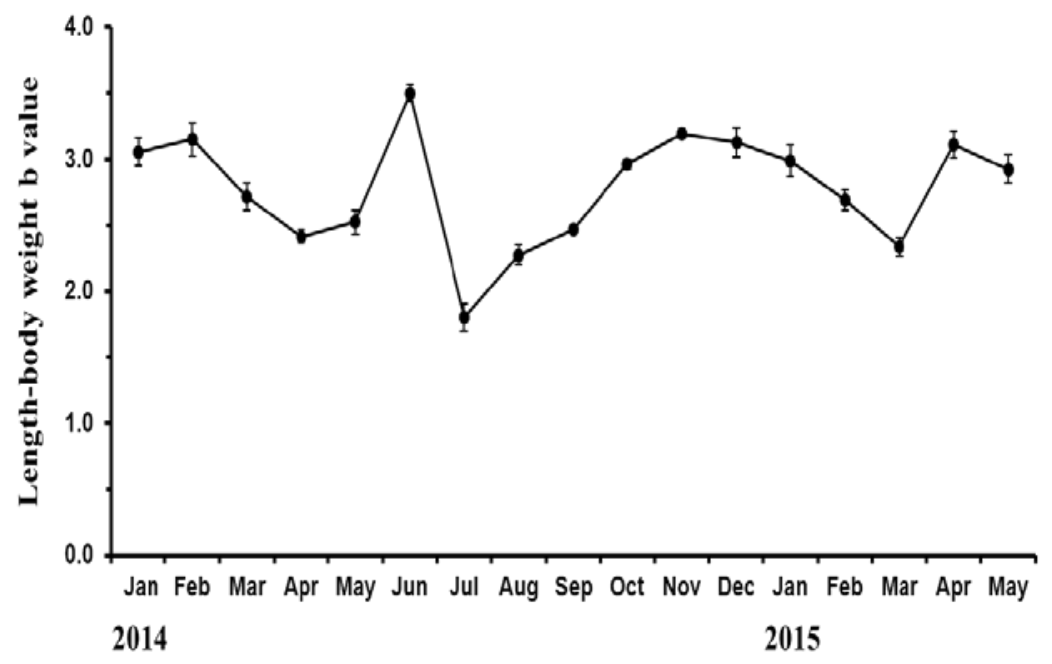

Fig. 9. Monthly variability in the $b$ values of length-body weight relationships of $L$. marginalis. Vertical bars represent standard error. 


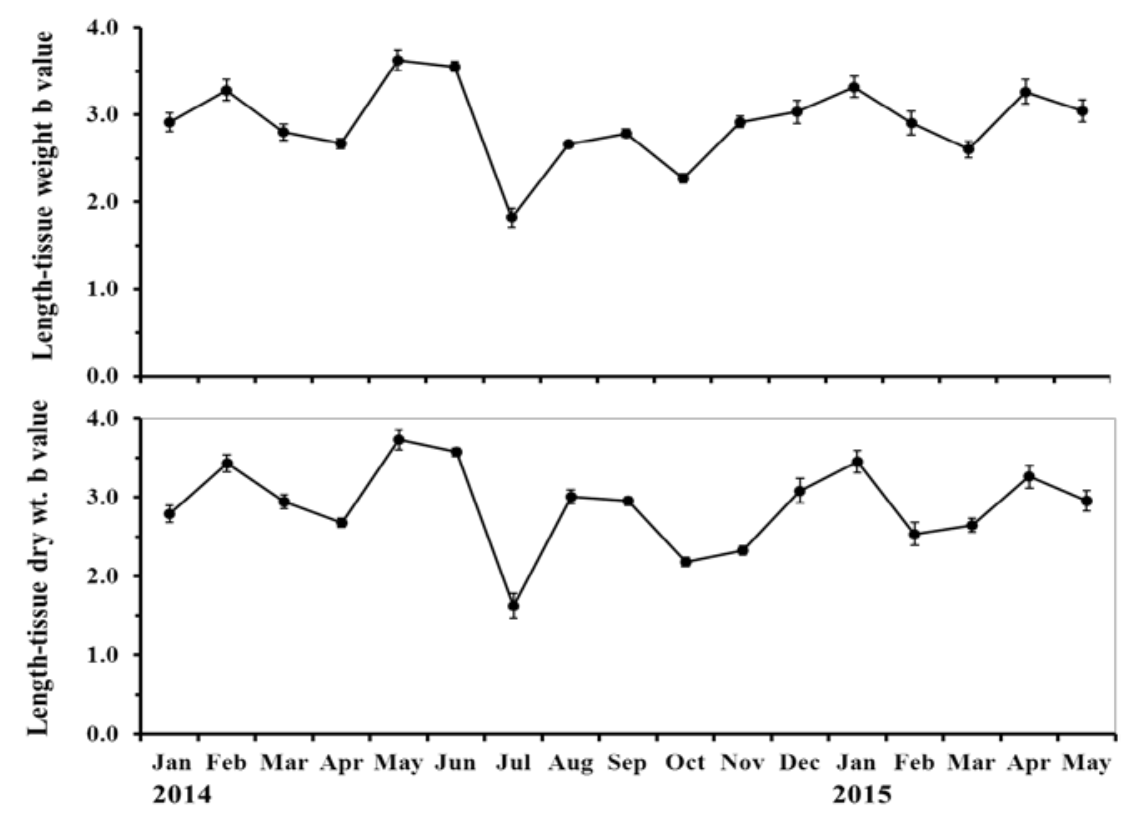

Fig. 10. Monthly variability in the $b$ values of length-tissue weight and length-tissue dry weight relationships of $L$. marginalis. Vertical bars represent standard error.

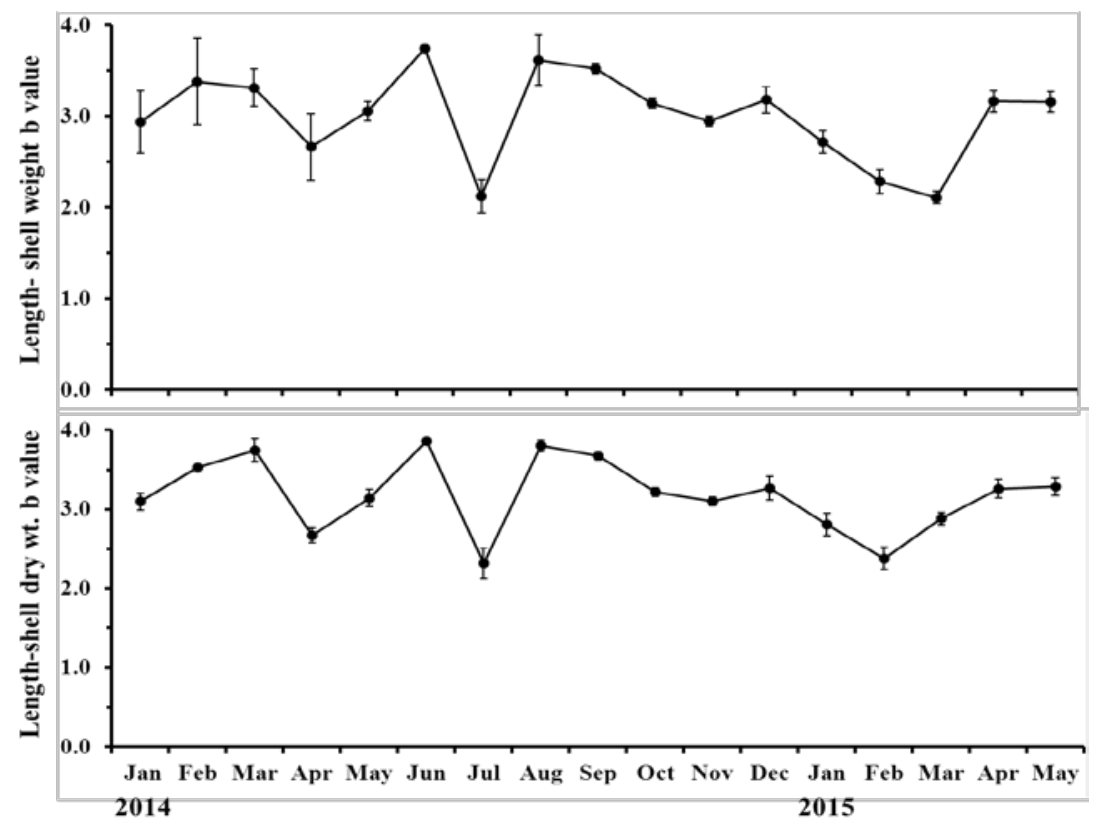

Fig. 11. Monthly variability in the $b$ values of length-shell weight and length-shell dry weight relationships of L. marginalis. Vertical bars represent standard error. 


\section{Discussion}

\section{Morphometric relationships}

A variety of environmental factors are known to influence shell form in bivalves. The size of shell is more affected than their shape by fluctuation of ambient environmental conditions (Wilbur and Owen 1964, Seed 1968). Thus shape, rather than size generally provides more accurate knowledge on the dimensional relationships. During the present study period, the $b$ values of length-breadth and length-width showed monthly fluctuations (Fig. 5), which may be due to the fact that, the shape is controlled by genetics of the organism and size by ambient environment as stated by Seed (1968). The $b$ values of morphometric relationships are usually compared between dimensional growth of related species or same species in various geographical regions. In the present study, the $b$ values of length-breadth and length-width relationships were 0.482 and 0.3203 , respectively. The $b$ values of length-breadth and length-width relationships of the freshwater mussel $P$. corrugata from river Kempuhole, India were 0.585 and 0.333 respectively (Ramesha and Thippeswamy 2009). The $b$ values of length-breadth relationship of Amblema plicata at different sampling sites varied between 0.696 and 0.758 in the river Mississippi, USA (Hart 1999). The morphometric relationships of $L$. marginalis in the present study are in good agreement with the abovementioned studies.

\section{Length-weight relationships}

The length-weight relationship provides a mathematical expression to the relationship between two variables, length and weight, and also provides a measure of deviation between two variables indicating the state or general wellbeing of an organism. Length and weight of organisms have been highly correlated with lifehistory measures in cross taxonomic comparisons (Peter 1983). The bivalve molluscs are known to show variations in quality of meat depending on their environmental and physiological conditions as well as seasons. The skewed relationship in the present study indicated that short individuals were light and long individuals were heavy. Such observations in other bivalves have been reported by Ramesha and Thippeswamy (2009), Bhattacharya and Banik (2012) and Sethi et al. (2012). Normally, as the age increases, the weight also increase; however, some individuals of the same age showed different weight and these differences could be due to reproductive strategies and environmental variations (Bauer 1987, Haag and Station 2003, Ravera et al. 2007).

In fisheries research, length-weight relationships are important for the estimation of weight, where only length data are available and as an index of the condition of the animal (King 1995). The length-weight relationship is also an important measure for identifying the condition of bivalves in all stages of its life cycle. It helps to compare the condition of the bivalves in the context of pollution within the species or between the species. In the present study the $b$ value of length-body weight, length-wet tissue weight, length-dry tissue weight, length-shell weight, length-dry shell weight relationship were 2.8282, 2.5905, 2.6296, 2.8769 and 2.9979 respectively. Malathi and Thippeswamy (2011) studied the Allometry and condition index in the freshwater mussel Parreysia corrugata (Müller 1774) from river Malthi in the Western Ghats, India from March 2007 to June 2008 and reported the $b$ value for length- total weight, length-wet weight, length-shell weight and length-dry weight relationships were $2.6660,2.6684,2.7124$ and 2.9370 respectively, which are more or less similar with the findings of the present study. Ramesha and Sophia (2015) studied the allometry and condition index of the freshwater mussel Parreysia favidens (Benson 1862) during April 2005 and May 2006 inhabiting the west flowing river Seeta at Seetanadi in the Western Ghats, India. They reported the $b$ value for length-total weight, length-wet weight, length-shell weight and length-dry weight relationships were $3.066,3.054,3.139$ and 3.110 respectively and are higher than the respective $b$ values of the present study. 
Suryawanshi and Kulkarani (2014) studied the comparative length - weight relationship of fresh water mussels, Parreysia corrugata and Lamellidens marginalis from Nanded region, Maharashtra, India. They reported the $b$ value 3.2631 for Parreysia corrugata which is higher than present study and 2.6084 for Lamellidens marginalis which is similar to the present study. Lowe-McConnell (1987) stated that many aspects could be accountable for the changes in growth such as variations in the habitat, activities, food availability and seasonal growth rates. The bivalves displayed marked seasonal variations in weight and biochemical content of the soft tissue (Williams and McMahon 1989). In bivalves, the gonadal growth and maturation precedes with bulkiness of soft body and consequent high body weights. In the present study such sudden shift of $b$ values indicates the onset of maturation and gonadal growth of the bivalve.

\section{Conclusion}

This study provides an important baseline on the shell and tissue growth, morphometric relationship and length-weight relationship of $L$. marginalis from a freshwater ecosystem of the northwest of Bangladesh. The results of the study would be an effective tool for the resource manager to take appropriate strategies for the sustainable management and conservation of this species in the freshwater habitat in Bangladesh.

\section{Acknowledgement}

The authors are grateful to the Department of Fisheries, University of Rajshahi, Bngladesh to facilitate the research and thankful to the Ministry of Science and Technology for financial assistance for this research.

\section{References}

Bauer G (1983). Age structure, age specific mortality rates and population trends of the freshwater pearl mussel (Margaritifera margaritifera) in north Bavaria. Arch. Hydrobiol., 98: 523-532.

Bhattacharya P and Banik S (2012). Length-weight relationship and condition factor of the pabo catfish Ompok pabo (Hamilton 1822) from Tripura, India. Indian J. Fish, 59: 141-146.

Budha PB and Daniel BA (2010). Parreysia favidens IUCN 2012. IUCN Red List of Threatened Species. $<$ <ww.iucnredlist.orgs.

Haag WR and Staton JL (2003). Variation in fecundity and other reproductive traits in freshwater mussels. Freshwat. Biol., 48: 2118-2130.

Hart RA (1999). Population dyanamics of unionid mussels in lake Pepin, upper Mississippi River, Minnesota and Wisconsin, PhD thesis. The North Dakota State University of Agriculture and Applied Sciences, USA.

Huxley JS and Tessie G (1936). Terminology of relative growth. Nature, 137: 780-781.

King M (1995). Fisheries biology assessment and management, Blackwell Science Ltd., Fishing News Books, Osney Mead, Oxford, pp. 341.

Lomte VS and Jadhav ML (1980). A study on the crystalline style of freshwater mussel, Parreysia corrugata. Hydrobiologia, 69: 175-178.

Lowe-McConnell RH (1987). Ecological studies in tropical fish communities. Cambridge University Press, London, pp. 382.

Malathi S and Thippeswamy S (2011). Morphometry, length-weight, and condition in Perreysia corrugate (Muller 1774) (Bivalvia: Unionidae) from river Malthi in the Western Ghats, India. Int. J. Biol. Sci., 2(1): 43-52.

Moorthy KS, Naidu MD, Chetty CS and Swami KS (1983). Changes in carbohydrates metabolism in tissue of freshwater mussel (Lamellidens marginalis) exposed to phosphamidon. Bull Environment Contamin Toxicol., 30: 219-222. 
Nagabhushanam R and Lohgaonker AL (1978). Seasonal reproductive cycle in the mussel, Lamellidens corrianus. Hydrobiologia, 61: 9-14.

Nagabhushanam R and Lomte VS (1971). Biochemical studies in freshwater mussel, Parreysia corrugata. Hydrobiologia 37: $545-552$.

Pauly D (1983). Some simple methods for the assessment of tropical fish stocks. FAO Fisheries Technical Paper, 235: 52.

Peter RH (1983). The ecological implications of body size. Cambridge University Press, Cambridge.

Ramesha MM and Thippeswamy S (2009). Allometry and condition index in the freshwater bivalve Parreysia corrugata (Muller) from river Kempuhole, India. Asian Fish Sci., 22: 203-214.

Ramesha MM and Sophia S (2015). Morphometry, length-weight relationships and condition index of Parreysia favidens (Benson, 1862) (Bivalvia: Unionidae) from river Seeta in the Western Ghats, India. Indian J Fish, 62 (1): 18-24.

Ravera O, Frediani A and Riccardi N (2007). Seasonal variation in population dynamics and biomass of two Unio pictorum mancus (Mollusca, Unionidae) population of two lakes of different trophic state. J. Limnol., 66: 15-27.

Reiss MJ (1989). The allometry of growth and reproduction, Cambridge University Press, New York.

Seed R (1968). Factors influencing shell shape in Mytilus edulis L. J. Mar. Biol. Ass., 48: 561-584.

Sethi SN, Nagesh R and Venkatesan V (2012). Length-weight relationship of Macrobrachium lar (Fabricius 1798), an endemic freshwater prawn in streams and ponds of Andaman and Nicobar Islands. Indian J Fish, 59: 157-161.

Suryawanshi AV and Kulkarni AN (2014). Comparative study of length-weight relationship of $P$. corrugata (Muller), and Lamellidens marginalis (Lamark), from Nanded region, Maharashtra (India). Indian J. L. Sci., 3(2): 77-80.

Wilbur KM and Owen G (1964). Growth. In: Wilbur KM and Yonge CM (Eds.), Physiology of Mollusca, vol 1, Academic Press, New York, USA, pp. 211-242.

Williams CJ and McMahon R F (1989). Annual variation in the tissue biomass and carbon and nitrogen content in the freshwater bivalve Corbicula fluminea relative to downstream dispersal. Can. J. Zool., 67: 82-90. 